DOI https://doi.org/10.36059/978-966-397-176-6/83-103

\title{
GLOBAL FACTORS INFLUENCING THE TRAINING OF TEACHERS OF HIGHER EDUCATION INSTITUTIONS IN THE CONTEXT OF A MASTER'S DEGREE
}

\section{Sushchenko T. I.}

\section{INTRODUCTION}

Objective changes in human life, international trends in the comprehension of the main foundations of a qualitatively new understanding of world and national values should stimulate, in particular, higher education to form a planetary vision of the role of the natural growth of contacts, relationships, mutual obligations between nations, communities, countries; create a better order in the global and local dimensions of the purpose and reformation of higher education, develop qualitative methodological assessments in this direction, take into account the factor of unity and heterogeneity of national communities, the need for their social integration and sustainable development of spirituality and security of the humanity. That is why the whole world is interested and involved in the development of the complete higher education. Scientific forecasts about the radical changes in the current path of world development in the context of globalization indicate a radical revision of the existing values and way of life of the mankind, a radical change of stereotypes of relations and interactions in the system «man - nature - society - civilization». The ways of creating the necessary social and scientific environment with the aim of making global transformations into the existing tendencies of development and creation of an adequate system of higher education remain unexplored. The modern social science and Ukrainian pedagogical science have been left alone with the whole «universe» of problems related to globalization and integration unprecedented in the world.

In this connection, V. Kudin concludes that “... the main purpose of education in the new century is to teach people to live, act, create, rationally and carefully use natural resources, constantly replenish them. 
To learn to live in friendship with other countries and peoples, to eliminate forever wars, hostility, killings from life"1

V. Kudin's words are another argument for the urgent need to form a planetary education system, to develop a unified planetary pedagogy. In this regard, understanding of the sense-value ideal of the humanity and the integration of various sciences is gaining ground, this is facilitated by the need to solve a group of global and other problems, without which one cannot hope for the survival of the humanity and ensuring of its sustainable development.

In researches of many scientists, models of integration processes in formation of the personality of a modern graduate of a higher education institution had been constructed long before the question of globalization of educational space arose. In particular, according to A. Dzhurynskyi, the concept of education of the inhabitants of the Earth - as a common House of the mankind is approved and developed ${ }^{2}$.

Referring to the world experience of overcoming the crisis in education, L. Vorobiov, in particular, emphasizes that the most important task of educational integration is work aimed at spiritual rapprochement of peoples, overcoming mutual resentment and distrust between them ${ }^{3}$.

V. Kudin, analyzing the state of the modern world higher education, believes that changes in the social and political priorities of many countries of the world have led to a revision of the basic purpose of education, the transition from the education of a citizen of one state to the formation of the «citizen of the world», a responsible and educated person, whose morality has to achieve the level of compliance with the tasks that should be solved now. Thoughtful attitude to the creative heritage of other peoples will allow to see not only the difference, but also to find common in the attitude towards reality, will help to know the native one more deeply, will answer an important question: how to live together in peace and harmony, validate the experience of the system

\footnotetext{
1 Кудин В. А. Образование в судьбах народов (Дидактика нового времени). Киев : ПП «Гама-Принт», 2007. 218 с.

2 Джуринский А. Н. Сравнительная педагогика: учеб. пособие для студ. сред. и высш. пед. учеб. заведений. М. : Издательский центр «Академия», 1998. 176 с.

${ }_{3}^{3}$ Воробйова Л. С. Світовий досвід у подоланні кризи вищої освіти. Сучасний стан вищої освіти в Україні: проблеми та перспективи: тези доповідей Всеукраїнської науково-методичної конференції. К. : КНУ, 2000. С. 118-120.
} 
optimization of solving not only economic and environmental problems, but also guaranteeing harmony and culture of relationships between people ${ }^{4}$.

\section{Planet-oriented education is an important component of the modernization of professional training of teachers of higher education institutions}

The scientific idea that destructive civilization processes occur not only in nature, energy, demography, but, above all, they are different aspects of the «common human crisis», which are rooted deep in a human, in the very nature of the human being, comes into the picture more and more. It is unfortunately impossible to propose alternatives for the survival of an existing civilization on the basis of scientific knowledge only: a divided and hostile humanity is doomed, and only the united has a chance to survive.

Most scientists, researchers of global crisis processes (L. Vorobiov, A. Dzhurinsky, V. Kudin) warn, in this connection, that in conditions where, apart from national borders, humanity is separated by antagonistic tendencies, values and interests - financial, ideological, clan, religious, ethnic, etc., - much of the research aimed at identifying the root causes of the global crisis is ignored or given the label of scientific fanaticism or anarchism, or unwarranted fear mongering.

There is a need for the urgent formation of a fundamentally new concept of education, the development of higher education and the system of culture of human relations, aimed at universal human priorities, a fundamental rethinking of the paradigm of global survival of mankind, scientifically justified transition from the existing self-centered - to anthropocentric and sociocentric models of life and interaction from an individual to the humanity as a whole.

In such situations, as evidenced by the practice and historical retrospective, higher education, spiritual culture, under certain pedagogical conditions, can become guarantors of universal stability and integrity.

${ }^{4}$ Кудин В. А. Образование в судьбах народов (Дидактика нового времени). Киев : ПП «Гама-Принт», 2007. 218 с. 
But what is the global pedagogical problem? State policy in the field of development of professional higher education should be aimed at achieving the modern international standard by Ukrainian education, further development of national educational traditions, updating the content, forms and methods of augmenting the cultural and intellectual potential of the new generation of teaching staff, highly qualified multiskilled specialists, able to work in the mode of advanced system of higher education, in the conditions of rapid economic changes and globalization of relations, to introduce new systems of professional training taking into account all the advanced things, which have been developed in the world, European and national pedagogical science.

Modern science offers teachers a comprehensive view of the world and a human in it, its place and role on a society and international scale. Philosophical ideas about the limitless development of personal potential, about the noosphere, ethnogenesis, which have entered the social context, greatly expand and deepen understanding of the human nature, open new approaches to the activities of education institutions, pedagogical activity of a teacher, the content of which considers more clearly the creation of a Human, a professional.

These phenomena make the task of the modern higher education system more difficult. The most up-to-date scientific and human science information, which has been accumulated by many sciences over the last half a century, does not help. This knowledge is constantly being expanded and updated almost daily. They are immensely needed by modern educators, parents, finally, pupils and students for self-discovery, the avoidance of misfortunes and perversions that appeared before the most civilized societies in the new millennium in the field of education and preparation of new generations for life on a damaged planet in a number of dangerous threats to human survival. There are actually many zones on earth that are no longer possible for a person to live.

In this regard, the teacher's understanding of the importance of integration of various sciences is gaining strength, this is facilitated by the need to solve a group of global and other problems, without which one cannot hope for the survival of humanity and ensuring of its sustainable development. 
Among the tools that can be counted on by some of humanity in solving these problems, the most promising ones are pedagogical science and higher education, which is conceptually based on the progressive ideas of integration around the global problems of human life and each individual, in particular, taking into account the progressive ideas, initiated by the philosopher V.O. Kudin concerning the need to change many of its current ideals and aspirations, vision of life values. According to V. Kudin, «... with a reasonable understanding of the latest scientific and technological achievements, humanity will be able to return to the path of true progress, without destroying nature, but contributing to its improvement... To encourage the pursuit of cognition, creativity, creation, excellence, beauty, goodness, morality and humanity is the basis of updating the education system for the present time of human history» ${ }^{5}$.

Therefore, higher education today should focus on the formation of those universal values of life, in which there will be no place of aggression, harassment, violence, ruthless exploitation of others' labor, enrichment at the expense of others, the use of weapons as a means of domination over other countries and peoples.

The detachment of higher education from these global problems hinders any overall development of society, education, the individual itself, any citizen of the planet.

This, above all, explains the fact that everyone recognizes the fact that knowledge does not mechanically develop into humane and decent relationships or relations between people, and from them - into a style of behavior. The contrary cases are more widespread, when, for example, competent and even knowledgeable in legal codes people knowingly violate the rights of others, cut down forests for their own cottages, commit cynical financial fraud and see no sin in these actions against people and society, against their parents and children. In his time, K. Ushinski warned that knowledge does not automatically make a person educated.

${ }^{5}$ Кудин В. А. Образование в судьбах народов (Дидактика нового времени). Киев : ПП «Гама-Принт», 2007. 218 с. 
Scientists around the world are worried that we should no longer continue doing only what we want on Earth; that a person, wherever it lives, has to take responsibility - personal and historical - for all that is happening on the planet. Researchers substantiate scientifically the need for formation of planetary thinking by means of education, it is about the emergence of an interdependent and integrated world, about spirituality as an awareness of one's belonging to the whole world. The efforts of educators, therefore, should be directed to solving the global problems of survival of civilization, which requires pedagogical cooperation, cocreation and coordinated development of a new citizen of the Planet.

Scientists associate new model of human coexistence on Earth with aggravation of ecological crisis.

Education and upbringing should be the main factors of pedagogical influence on the preparation for the future life in terms of integrity, interdependence, responsibility and care, instead of a narrowly oriented model of life on Earth. We are all integrated into a single life system that supports the existence of each of us. The borders on the maps are conventional. Detachment is detrimental to us because the difference between us is insignificant compared to what unites us. Therefore, from whatever point of view we approach the paradigm of professionalism of a teacher of a higher education institution, it is necessary to take direct practical steps to participate in the research and solving of the considered global problems. The implementation of such steps requires a serious scientific substantiation of the response of research educators to such important questions:

- What should be the goals of higher education today that determine its content and organization?

- How to choose the content of planetary-oriented education that students should master?

- What are the criteria for evaluating the quality of higher education obtained in higher education institutions?

The answers to these questions determine the strategy of professional development of teachers of higher education institutions of any country, which should influence the future spiritual and intellectual pedagogical elite and the course of further transformations in Ukraine and all over the world. 
In general, it should be noted that the future prospects for integration of the educational space even into the European one are far from being defined, as well as the mechanisms of bringing human values closer to the unique cultures and values of peoples are not defined. At present, the study of pedagogy and the culture of peace, the creation of joint academic centers or at least laboratories, meeting the goals of integration, should be the most relevant issue, and in the near future - research institutes of planetary pedagogy.

The qualitative side of the future educational sector, the content of higher education depends entirely on the scientific and methodological support of the strategy of the culture of peace, which consists in:

- formation of the basic culture of a person, its ability to express its attitude to the world, to people, to itself in original national forms;

- understanding by teachers as teachers of humanity, who stand at the sources of society of the future, which form a person for all the mankind;

- restructuring of higher education into the system of education and development of the planetary culture of a person;

- transformation of the existing practice of authoritarianism in relations between subjects of educational institutions, cultural institutions of governmental agencies, public organizations based on the development and use of scientifically substantiated programs called «Towards a culture of peace» with an orientation to the world culture of peace, adequate feelings, needs and actions, responsibilities for safety, well-being, comfort and joy of life.

However, the existing traditional conceptual paradigm of a professional higher education institution ignores the accumulated scientific ideas of philosophy, theology, literature, social sciences, psychology, pedagogy about the peculiarities of the modern professionalism of a teacher and a student, a future specialist, as unique, complex human persons whose interests and motives do not always coincide with what the traditional educational environment of universities, institutes and departments offers to them.

The lack of research on this issue at the present stage of the development of professional pedagogy, a thorough study of the impact of the professionalism of the teacher on the harmonization of the development of students' professionalism in the new conditions of the 
society, taking into account the already existing scientific achievements of the theory and methodology of professional education needs a scientifically substantiated answer to such important questions as: will there be the acute need for spiritual interaction, the need for co-creation, the desire to sincerely and openly express their uniqueness, initiative, research activity, special spiritual mission, intellectual efforts and efforts of will, etc. at teachers and students in the traditional educational environment of higher education institutions?

Therefore, as the well-known researcher of these issues, the philosopher P. Saukh, confirms ${ }^{6}$, the dominant traditional model of professionalism of a teacher of a higher education institution, his/her pedagogical skills, despite its top priority in times of economic depressions, will gradually give up its positions, giving way to the cultural and personal one, which place emphasis on education as the process, in which its subjects have the opportunity to know themselves and realize their potential, improve themselves morally and develop their necessary pedagogical abilities according to the requirements of time.

Without this model of teacher professionalism, any changes related to the rapid social and progressive psychological reorganization of the minds of the world's people are impossible. Society needs a teacher with a keen perception of new knowledge, an increased tendency to make bold psychological decisions and appropriate risk, a humane and highly educated person, able to show optimal activity in the development of the own creative abilities. There is a need for mass development and enhancement of the creative potential of teachers who have «their own criteria of formation in themselves and others of new, more sophisticated forms of human life and human relationships ${ }^{7}$.

Indeed, is it possible to imagine a teacher of a higher education institution outside such roles as a researcher, organizer of live full contacts with scientists, students, their parents, as a practical psychologist, as a teacher of professional culture and consciousness, as

\footnotetext{
${ }^{6}$ Саух П. Ю. Сучасна освіта : портрет без прикрас : монографія. Житомир : Вид-во ЖДУ ім. І. Франка, 2012. 382 с.

${ }^{7}$ Саух П. Ю. Сучасна освіта: портрет без прикрас: монографія. Житомир: Вид-во ЖДУ ім. І. Франка, 2012. 382 с.
} 
an organizer, a converter of human relationships, social and moral realias?

Within the framework of traditional higher education, which continues to be based on verbal information presentation, lectures and seminars, there is an increase of socio-psychological dissatisfaction of the participants in the educational process, which is caused by both financial problems and socially inadequate psychological and pedagogical content of higher education, that forces everyone involved in training of teachers to seek out and find methods and techniques of person-centered learning. This requires a reassessment of the former conceptual strategy of the entire system of continuous education, change of existing theoretical models of teaching and retraining of teaching staff, a new understanding of the purpose of the profession of teacher in the conditions of updating of all spheres of life of society, sharp improvement of pedagogical training of teachers, modernization of the content of the master's training, improvement of the activity of all links of the master degree.

In the writings of Andrushchenko V.P., Balla H.O., Bekha I.D., Honcharenko S.U., Volkova NP, Ziaziun I.A., Korsak K.V., Kravchenko V.M., Kremen V.G., Luhovyi V.I., M.I. Mykhalchenko, Romanovskyi O.G., Savchenko O.Ya., Semychenko V.A., Sysoieva S.O., Slastonin V.O., Sushchenko A.V. and others, they point to the need for implementation of reforms that make the total and rapid modernization of professional training of future teachers on a person-centered basis possible.

\section{Areas of updating and optimization of professional training of teachers of higher education institutions in the context of the master's degree}

The goals, tasks, functions of higher education institutions, their purpose change. The higher education institutions that work for the future should not become domain-specific, but person-centered by essence, content, focused on human individuality, on the highest culture of human relations.

V. Kremen, exploring this problem, proves that modern civilization greatly expands and complicates the communicative environment, where 
a person constantly comes in many contacts having different geography, that in situations of competition the education faces a lot of new tasks, «the foremost among them is to leave authoritarian, repressive pedagogy in the past and move to pedagogy of tolerance. To establish an atmosphere of mutual respect of students in educational institutions. To move from subject-object relations between a teacher and a student, a professor and a student, to subject-subject one, where both parties would be active and efficient. We will not change the society and the state without these changes» ${ }^{8}$.

However, according to P. Saukh, the pedagogical education has become an outsider of higher education today, its strategy is to catch up, but not to get ahead. The higher education has ceased to be a real customer of the content and results of future training of a teacher. Even in pedagogical universities, the profession of teacher has become only one among the others. The future teacher is not formed as a subject of modern planetary, democratic, cultural and technological values» ${ }^{7}$.

Hence we can see the first way to improve the process of professional training of teachers of higher education institutions, aimed at the humanization of the educational process, the re-evaluation of all its components in the light of spiritual transformation function, which radically changes the content of the essence of the university pedagogical process focusing not on the subject, the content or even the method, but on the person ${ }^{9}$.

In such a situation, the organizers of the master's degree training are obliged to act as scientists, who are called to solve a new ethical problem, which requires of them a new civic position and spiritual selfcriticism. In practice, it looks like this: a teacher of master's students, captivating his/her students with an interesting training purpose, constantly evaluates his/her own experience and is always in a state of internal moral self-control. Otherwise there will be the knowledge alienation, and the knowledge will remain just an educational discipline

\footnotetext{
${ }^{8}$ Кремень В. Г. Освіта в структурі цивілізаційних змін (з трибуни загальних зборів Національної академії педагогічних наук України). Вища освіта України. 2011. № 3. C. $8-11$.

${ }^{9}$ Кремень В. Г. Філософія людиноцентризму в освітньому просторі : моногр.; АПН України. 2-е вид. К. : Т-во «Знання» України, 2010. 520 с.
} 
for master's students, that significantly narrows the subject of master's degree study.

By our assumption, we should begin with the understanding that any informatization or computerization will never diminish the role of a teacher in the spiritual development of a person, in the professional training of a highly qualified specialist.

In this context, it is extremely important to recognize the individuality of each future professional, his/her right to an independent trajectory of his/her professional career, a real analysis of his/her own needs in professional development. In this connection, the prognostic orientation of the teacher-led strategy of professional development and self-development in the languages of teaching in the master's degree, is of particular importance.

Therefore, a master's student, as a future teacher, in the first days of professional training should be recognized as a subject, the real creator of his own scientific and pedagogical professionalism, since his/her future teaching activity in its essence involves mainly not influence on students, but interaction with them. Orders, threats, punishments, influence from the point of view of force always cause only resistance. The professional development and self-development of a future teacher of a higher education institution depends on the extent to which his/her personality is the subject, the real creator of his/her professional activity.

This provision is experimentally confirmed by the results of many years of research of the laboratory «Scientific School of Training of Teachers» of the Classic Private University in Zaporizhzhia city, as evidenced by the valuable professional orientations of master's graduates, which have a significant impact on all aspects and the conscious attitude of a teacher to the profession on the basis of pedagogical analysis and characteristics of his broad motivation.

We believe that the teaching activity of a teacher is a simultaneous combination of science and art. In this process, the future teacher acts as a researcher. His thoughts are reminiscent of the search for answers to complex professional questions by the efforts of the mind, will and culture, while showing individual pedagogical art. Theory and practice are combined here for the sake of co-creation with students and mutual professional spiritual enrichment. 
Such a process is always easy and simple for students, but difficult for a teacher. In his time K. Ushynskyi made such a professional credo for himself: The more difficult it is for a teacher, the easier it is for a student, which is directly related to the preparation of a teacher of a higher education institution. Both polemic, and constructive dialogue, and convincing observation experience work here.

Particular attention needs to be paid to improving the master's pedagogical process, in which the future teacher, learning to feel like a full-fledged teacher, has received a great interest in professional growth, confidence that in his successful activity he can advance in his professional status.

In this regard, we consider the pedagogical process of professional training of teachers of higher education institutions as a process of spiritual interaction of teachers and master's students in the conditions of psychologically favorable climate of educational relations, dialogical culture and intellectual co-creation ${ }^{8}$.

For harmonious mastering of pedagogical knowledge by master's students there is a need for experience of joint creative activity with a teacher and a system of motivated socially valuable attitudes towards understanding of the new social role of the master's student, his/her new status. The optimum spiritual and practical assimilation of the necessary information, humanization of teaching occurs only under this condition.

Another way of improving the master's degree training of teachers of higher education institutions is to provide the training activity with vivid research activity, its focus on the modern solution of a new ethical problem.

Typically, this process is accompanied by comprehensive and accessible collective proposals, the search for the best, most effective solutions, the analysis of the sprouts of an innovative approach. The pedagogical process in this case naturally and imperceptibly for the students becomes a scientific search, in which all its attributes are present: doubt, hypothesis, analysis, search, and as a result - correction of pedagogical attitudes, setting of new problems and solving them in conditions that stimulate a new collective creative search.

We consider this process as the highest form of socially significant activity of the teacher, because he/she himself/herself acts as a direct 
creator and «developer» of educational topics, professional situations, manuals and recommendations; his/her activity is basically aimed at awakening of complete independence and striving for originality, rationality and search of various methods of training and education.

Therefore, the pedagogical process in the master's degree training is a goal-oriented and controlled co-creation of teachers and master's students, based on the unexpected coverage of multivariate, optimal and original pedagogical tasks and decisions, which made it necessary to form its most important goals, such as:

- formation of innovative professional attitude of master's students;

- creating an atmosphere of open and free creative competition, discussion, favorable educational interpersonal relationships;

- by means of psychologically expedient technology (persuasive influence, attraction, «phenomenon of social orientation», etc.) to form high-moral professional attitudes and personal positions, transforming them into the own system of values.

The goal of the master's pedagogical process is based on the experimentally established facts that $90 \%$ of what a person does, about $50 \%$ of what he/she sees, and only $10 \%$ of what he/she hears is stored in a person's memory under constant conditions. Therefore, the most effective form of study in the master's degree training should be based on the active involvement of the master's students in the relevant pedagogical actions. This explains the development of the peculiarities of the pedagogical process in the system of master's training, aimed at the development of a high level of professionalism, which in our opinion, in the future, will assume to a greater extent not only scientific methodological and cognitive functions, but also professional and spiritual ones. This is the only system, in which the research activities of teachers and master's students are directly and organically combined with acute problems of higher education, which promotes and stimulates the purposeful, continuous spiritual self-development of teachers, which is measured by the high culture of professional co-creation of the subjects of the master's pedagogical process, the art of professional selfimprovement, active creative self-expression. 
Hence - the features of the master's pedagogical process and the main directions of adaptation of future teachers to the conditions of modern society, determined by us on the basis of long researches:

- providing spiritual and intellectual interaction and co-creation in the classroom, which results in many pedagogical findings and ideas;

- development of a stereotype for novelty, non-standard view on;

- preparing master's students for reassessment of past professional experience, reviewing of established pedagogical positions;

- prompting a rethinking of existing common cultural inquiries; readiness to find ways of successful professional self-improvement;

- the master's students attainment of a special qualitative state in style, behavior and attitudes, manifested in the mutual conceptual «refinement» of each other, a special creative atmosphere of educational communication, in the ability to kindly argue, listen, express any opinion;

- directing teaching activities to enhancement of professional confidence, reduction of the passion for negatives, to serious shifts in the freedom to choose appropriate, scientifically substantiated pedagogical means;

- purposeful and active discovery and development of the individual inner spiritual potential of masters, especially such qualities as: calm and creative attitude to changes and adaptation to them, to comparisons and hypotheses, various kinds of creative challenges, etc.;

- engaging master's students in the scientific substantiation of their naturally created attitudes towards the profession.

Existing features distinguish the pedagogical process of the system of traditional higher education in that they not only teach mature people here, but also re-educate them, help to overcome resistance to previously formed stereotypes, awaken individual attitude to them.

In this work we cannot ignore all the previous experience of the master's students, their style to make the best use of it (experience) for the purpose of further professional advancement, given the fact that in the course of master's training new pedagogical knowledge is not accepted on faith, even if it is supported by positive facts of application in practice. Old experience often becomes a barrier to new knowledge. 
This is explained by the fact that everything new requires additional time for retraining and adaptation, and the psychological adjustment itself is objectively connected with some efforts. Therefore, even reasoned arguments for the necessity and feasibility of additional efforts in the development of new knowledge does not always contribute to overcoming such contradiction.

In order to reduce or eliminate the negative effects of bias, the pedagogical process should be organized in such a way as to lead masters to their conscious rejection of stereotypes. This can be achieved through the joint creative search for pedagogical truth, the collective understanding of the advantages and benefits of timely rejection of past stereotypes, but the peculiarity of this interaction is that nothing can be imposed in a master's audience.

We can say without exaggeration: conscious professional co-creation can exist only where there is a worthy goal, sincere awareness of it, pedagogical prediction and forecasting common with the teacher, collective understanding of optimal instrumentation, delicate influence of experienced and authoritative teacher, deep analysis of the achieved result, correlating it with the goals set, etc.

If all this is a priority in the master's training system, an infinite number of innovative teachers will appear.

Many years of experience in organizing the teaching process in different master's audiences have shown that professional co-creation achieves the goal when a joint, purposeful search for pedagogical truth promotes:

- raise of the pedagogical consciousness to a higher professional level.

- facilitation of the transition from study to self-study;

- development of the ability to adequately perceive one's own individual qualities, accurate prediction of how they may influence actions and professional behavior;

- stimulation of free thinking, maximum emotional involvement of each master in a specific creative situation;

- training of sensitivity to the emotional state of others; 
- acquisition of new skills of active analysis of complex pedagogical phenomena, intrinsic properties and pedagogical experience, professional actions, their motives.

Nowadays, national pedagogy examines many of these common human problems, which were perceived as abstract yesterday, and today they become more relevant, more specific, touching all the inhabitants of the planet in search of a better education system, ways of integration into the European educational space, overcoming planetary provinciality, deformation of moral consciousness. Such searches for progressive educators are taking place all over the world. This search is of the utmost importance, because if now we do not make every effort to improve the moral and psychological climate in all spheres, to awaken conscience, duty, humanity and responsibility by means of education, then in the near future all negative phenomena in human relations, in relations between peoples and countries, that are being observed today, can have catastrophic consequences.

This approach is explained by the fact that any education system can serve as a means of self-development and successful professional selfrealization only when the internal conditions are created for this purpose, for which purpose there is a need for professional educators, whose thinking is not limited to special knowledge, but has features of universalism, fundamentality and moral and spiritual basis, a teacher who could improve the content of his/her professional activity, and be an example of high spirituality, spiritual culture.

A modern teacher should decisively turn his face to culture and upbringing, because if in the future he/she will absolutize his mission as a translator of knowledge - there is no future in such an education, it will degenerate into a remote learning system and will die out itself.

So, it is about creating a stimulating system of education that a master's student would perceive as something extraordinary and essential for work, where he could choose the kinds of cognitive activity, where there is a constant search for optimal pedagogical solutions designed for the future.

Critical analysis of pedagogical arguments put forward in favor of a stimulating system of training of master's students, is due to the conviction that only such a system can contribute to the creation of 
individually modified forms of professional training, work on the development of individual creative abilities.

And one more feature. Since a teacher works in the spiritual sphere, it should be not so much about learning, but about his/her active transformative function, in which pedagogical knowledge is perceived through individual experience, their required motivational setting.

Therefore, the professionalism of a modern teacher is defined as his ability to reach the heights of professional development and selfdevelopment of master's students in the process of professional training in a minimum amount of time.

But the question arises, under what pedagogical conditions is the peak professional development of the future teacher achieved?

In this regard, the reorganization of the master's training system must begin with the abolition of the existing stereotype of treating the teacher as an indirect personality, with the acceleration of finding ways to encourage the professional self-improvement of master's students as vivid and unique individuals, while constantly working with everyone. Psychologists rightly assert that we are not a toy of our genes, a product of the environment, but we are both of them, and in addition, we are potential and conscious creators, active subjects of our own development. Therefore, training should not be limited to the acquisition of knowledge and skills, it must first of all develop the ability to consciously manage their professional activities, to indicate ways to achieve the predictable worthy pedagogical goals, which are set based on the ideals and values accepted by society, with which they relate their life path as a whole.

It is important take into account that the pedagogical process in th emaster's degree training never starts from scratch. The students have a well developed selective and consciously critical attitude to the offered pedagogical knowledge. They either assign it or reject it. In the situation of professional co-creation, when masters are the subjects of active influence on the course of the pedagogical process, the teacher and the master together rise to a new degree of creativity. Without noticing, they are always the creators of new pedagogical knowledge.

Here the important pedagogical law inevitably works: the more active the participation of master's students in creative-transformative pedagogical activity, the faster and more successful the training develops into a professional self-education and self-improvement. We see a very 
important specific role of professional development of a future active teacher in this.

However, the process of development of professionalism and creativity is not easy. In speaking of the complex interinfluence of motivational and cognitive components on the development of professionalism and pedagogical creativity of a teacher, we should avoid in every way an excessive simplification of causal relationships between them. The fact is that the positive motivation during training sessions in the master's degree training not always clearly contributes to the creative rethinking of stereotypes in specific cases and situations. Effective internal connections of these components are mediated through many other influences, including the conscious creative activity of the administration, of the whole staff of a higher education institution.

We should not turn the blind eye to the fact that many creative teachers, which still develop their professionalism, depend on hardly creative leaders, who sometimes allow themselves to encourage the grayness of individual teachers in teaching, putting them on a par with talented and creative teachers. For this reason, many wasted and sometimes lost pedagogical talents are devalued.

However, there is every reason to say that professional co-creation in the process of master's training dramatically increases its results, helps the future teacher to understand the eternal question: why teachers with knowledge, experience and even with a sincere desire to work professionally, successfully, do their pedagogical work in a different way.

Learning professionalism and co-creation only with pedagogical textbooks is like trying to master the secrets of the pianist's craft using a self-teaching guide. Pedagogical co-creation requires a great deal of emotional and intellectual tension, mobilization of attention to a person and a team, with which a teacher started professional communication. Of great importance is the mutual desire and the need to understand something deeply, to rethink old experience, and if there is strong and convincing evidence - to abandon past shortcomings and mistakes.

The results of our study prove that: to this end, it is useful and advisable to come together more often for a meaningful professional dialogue, an honest clarification of current problems or controversial issues. Dialogue contributes to co-creation when urgent issues are offered in terms of professional necessity, morality and common human 
values. Then there will be grounds for exchange of thoughts, passionate «fighting» of different forces, desire to reconcile their views and guidelines with general existing pedagogical ideas, to share impressions of their own vision of the problem, the desire to critically reflect what others have said. In other words, in dialogue there is always a conditioned expectation of creative interaction, the result of which is professional community and a special internal spiritual connection. For the future teacher - it is also a training ground for practicing the skills of professional interaction, which activates the thought of a student, awakens his/her desire to argue openly, speak candidly with a teacher, learn naturally and easily his/her science, make the pedagogical process exciting and optimal from the point of view of pedagogical goals.

Thus, the results of our research confirm the important conclusions of the famous philosophers I. Ziaziun, V. Kremen, K. Korsak, V. Kudin and others that the processes of integration and globalization require not only a significant upgrade of the higher education of Ukraine, but also strengthening of the pedagogical component of the civilization process (V. Kremen), formation of humanity as a responsible communicative community and corresponding higher education, special professionalism of a teacher of a higher education institution.

\section{CONCLUSIONS}

1. The process of formation of a new model of teachers' professionalism requires special attention from the state, the essence of which is to motivate professional growth. As noted above, it is positive that today there is a definite tendency concerning determination of ways to stimulate teachers' activity, improve their financial situation and life.

2. In our opinion, the development of objective criteria for assessing the professional activity of teachers, in particular filling the professional and qualification characteristics with new content, will contribute to improvement of the professionalism of teachers, the efficiency of their work, which will positively affect the solution of the complex tasks such as:

- selection (including hiring) of teachers on a competitive basis, certification, annual assessment of the quality of accomplishment of their workload, growth of career development on this basis;

- formation of promising staff reserve of teachers and organization of effective innovative pedagogical work with them; 
- creation and improvement of modern programs of training, retraining and advanced training of teachers in accordance with new functions and tasks they perform, creation of new professiograms, which are based on the idea of formation of the desired planetary image of a teacher through a set of scientifically substantiated components of the planetary approach to professionalism, moral and psychological, ethical qualities.

3. The formation of a new model of professionalism of a teacher depends on the solution of several interrelated professional and ethical problems, which is reflected in the priority areas of adaptation of universities to European standards, taking into account the national peculiarities of Ukrainian education, implementation of the European level of legal guarantees, material and moral protection, formation in society of the relevant attitude to the professionalism of a teacher of a higher education instituton.

\section{SUMMARY}

The section analyzes the global factors of influence on the world educational processes, in particular, on the updating of professional training of teachers of higher education institutions and the content of new professionalism. Particular attention is paid to the improvement of the master's pedagogical process, in which future teachers are trained. Such training is considered as a process of spiritual interaction between teachers and master's students in the conditions of psychologically favorable climate of educational relations, dialogical culture and intellectual co-creation. The most effective way of successful training of teachers of higher education institutions is to provide the master's training process with a vivd research activity that has all its attributes: doubt, hypothesis, analysis, search, and as a result - correction of pedagogical attitudes, settng new problems and solving them in conditions that stimulate active collective creative search. This process is considered in the chapter as the highest form of socially significant activity of a teacher of a higher education institution.

\section{REFERENCES}

1. Воробйова Л. С. Світовий досвід у подоланні кризи вищої освіти. Сучасний стан вищої освіти в Украӥні: проблеми та 
перспективи: тези доповідей Всеукраїнської науково-методичної конференції. К. : КНУ, 2000. С. 118-120.

2. Джуринский А. Н. Сравнительная педагогика: учеб. пособие для студ. сред. и высш. пед. учеб. заведений. М. : Издательский центр «Академия», 1998. 176 с.

3. Корсак К. В. Світова вища освіта. Порівняння i визнання закордонних кваліфікацій і дипломів : монографія / За заг. ред. проф. Г. В. Щокіна. К. : МАУП; МКА, 1997. 208 с.

4. Кремень В. Г. Освіта в структурі цивілізаційних змін (3 трибуни загальних зборів Національної академії педагогічних наук України). Вища освіта України. 2011. № 3. С. 8-11.

5. Кремень В. Г. Філософія людиноцентризму в освітньому просторі : моногр.; АПН України. 2-е вид. К.: Т-во «Знання» України, 2010.520 с.

6. Кудин В. А. Образование в судьбах народов (Дидактика нового времени). Киев : ПП «Гама-Принт», 2007. 218 с.

7. Саух П. Ю. Сучасна освіта : портрет без прикрас : монографія. Житомир : Вид-во ЖДУ ім. І. Франка, 2012. 382 с.

8. Сущенко T.I. Особенности педагогического процесса в эпоху приоритета личности. Научный поиск в воспитании; парадигмы, стратегии, практика. 3-я Международная научно-практическая конференция 24-25 марта 2011 года: сборник докладов и тезисов выступлений. Авт.-сост. В.П. Сергеева, Н.В. Чернышева, Н.Н.Рудь, А.А. Белов. - М.:МГПИ, АПК и ППРО, 2011. 438 с. науч.трудов. 2011. C. 34.

\section{Information about the author: Sushchenko T. I.,}

Doctor of Science in Professional Education, Professor, Professor of the Education and Management of Educational Institution, Classical Private University 70b, Zhukovskoho str., Zaporizhia, 69002, Ukraine 